\title{
Inclusão e exclusão em Brasília
}

\author{
Inclusion and exclusion in Brasília
}

Frederico de Holanda[a] (1)

[a] Universidade de Brasília, Brasília, DF, Brasil

Como citar: Holanda, F. (2020). Inclusão e exclusão em Brasília. urbe. Revista Brasileira de Gestão Urbana, v.12, e20190306. https://doi.org/10.1590/2175-3369.012.e20190306

\section{Resumo}

Os estudos de morfologia urbana são influenciados pela literatura pregressa, pela formação disciplinar dos pesquisadores e pela cidade onde sua instituição está localizada. No caso de Brasília, isso é ainda mais verdadeiro. Este artigo discute os trabalhos realizados no âmbito de um grupo de pesquisa estruturado há 35 anos e mostra como as peculiaridades da capital brasileira são desveladas. Aflora uma cidade peculiar, onde fragmentação, baixas densidades, dispersão no território e forte estratificação socioespacial são atributos fundamentais.

Palavras-chave: Brasília. Morfologia urbana. Fragmentação. Dispersão. Segregação socioespacial.

\section{Abstract}

Studies in urban morphology are influenced by previous literature, by the disciplinary formation of the researchers and by the city in which their institution is located. In Brasilia, this is even more evident. This article discusses the products of a research group which is organized 35 years ago and shows how the peculiarities of the Brazilian Capital are revealed. A peculiar city emerges, in which fragmentation, low densities, dispersion and a strong socio-spatial segregation are paramount.

Keywords: Brasília. Urban morphology. Fragmentation. Dispersion. Socio-spatial segregation.

\section{Introdução}

Os estudos de morfologia urbana têm influências diversas: nossa formação, o estado da arte em nosso país e no mundo e as transformações urbanas recentes. É somado a elas o usufruto da própria cidade que habitamos: a maneira como os lugares de nossas vidas, particularmente nosso sítio urbano, afetam nossos corpos e nossas mentes decerto nos impele a refletir em determinadas direções.

Em se tratando de Brasília, é mais verdade ainda: viver aqui significa estar, concretamente, no olho do furacão de uma das mais acirradas polêmicas em nosso campo, uma arena cheia de argumentos do tipo "ame-a ou deixe-a". A cidade é jovem, se suspendermos por um momento as preexistências no território, que não são desprezíveis - dois pequenos núcleos urbanos, um de 1850, Planaltina, e outro de 1930, 
Brazlândia, ambos a ficar dentro dos limites da municipalidade de Brasília quando de sua criação. Quase a completar 60 anos da inauguração (2020), duas categorias ainda distinguem seus habitantes e a maneira como entendem e vivem a capital: nativos e forasteiros - ser um ou outro implica problemas distintos do distanciamento necessário para a compreensão do fenômeno. Nativos desenvolvem uma familiarização que naturaliza a cidade, até o ponto em que sejam forçados a repensá-la a partir do contato com realidades de outras urbes - o hábito embota a crítica; nos forasteiros, dá-se o contrário, todavia não menos problemático: o choque com algo tão distinto de seus lugares de origem (se vieram de cidades pré-modernas, como praticamente todos) impele-os a um estranhamento igualmente danoso à reflexão crítica, pois tendem a avaliar a cidade, particularmente sua configuração, como "inadequada" ao convívio do modo que o conheciam antes - e repetem os bordões "cidade deserta", "sem ruas", "sem esquinas".

Mesmo vivendo a cidade por quase meio século - aqui cheguei em 1972 -, pertenço à categoria dos forasteiros (para minhas crianças, tendo aqui nascido, é o contrário). Ter habitado 28 anos em cidades pré-modernas empurra-me ao inverso da naturalização - e a postura tão perversa quanto: o choque diante de ambiente tão "estranho" (Hillier, 1996). Brasília, a cidade real, no entanto, não é natural nem estranha - então, o que é para além das percepções sensíveis?

Nas linhas anteriores, há indicações do tipo de postura reflexiva que adoto, ao referir: 1) como a cidade, particularmente sua configuração, afeta as pessoas - suas formas e seus espaço tratados como variável independente, afetando corpos e mentes de várias maneiras (quintessência do "método DIMPU"); 2) o convívio - especulações na intersecção entre estudos morfológicos e comportamentais; 3) as subjetividades - um pensar em interface com a epistemologia fenomenológica, ao trazer os variados sujeitos para a boca de cena; 4) finalmente, ao atender o chamado desta coletânea, como as preocupações informam o estudo de morfologia urbana, particularmente na Faculdade de Arquitetura e Urbanismo (FAU) da Universidade de Brasília (UnB), onde venho labutando desde que cheguei ao Planalto Central do país, mas en passant também em outras instituições.

Na FAU-UnB, a cidade tem sido tema recorrente: para alimentar o ensino, os estudos de morfologia urbana têm se debruçado sobre a capital, embora não exclusivamente. Para congregar colegas relacionados ao tema, fundamos 35 anos atrás (1984) o grupo de pesquisa Dimensões Morfológicas do Processo de Urbanização (DIMPU), registrado no Diretório de Grupos de Pesquisa no Brasil - CNPq, até há pouco coordenado por mim e agora sob a batuta de Gabriela Tenorio. A ideia central é examinar a arquitetura como variável independente, que afeta corpos (maneiras práticas) e mentes (maneiras expressivas) dos sujeitos. No âmbito acadêmico de Brasília e no de nossa FAU, não é o único grupo a estudar a cidade (mencionarei outros colegas), e nem todos os membros do nosso grupo a têm por assunto central. Contudo, neste texto, por razões de familiaridade e de espaço, enfocarei nos trabalhos do grupo e na temática brasiliense ${ }^{1}$.

Adotamos uma visão abrangente de arquitetura, pela qual há um saber inscrito em toda e qualquer manifestação, implícito ou explícito, popular ou erudito, subjacente ao barraco do favelado ou à Casa de Canoas, de Oscar Niemeyer: carece considerar admiráveis arquiteturas que estão debaixo de nossos narizes, mas que não vemos e que mergulham na história por milênios, como condição sine qua non para agirmos secularmente. Uso o termo no sentido do historiador israelense Harari (2018) em seu livro 21 lições para o século XXI, explicado nas palavras-chave: verdade - baseada em observações e evidências, não na fé; compaixão - referida na minimização do sofrimento do outro; igualdade - que distingue "singularidade" de "superioridade" de uns sobre outros; liberdade - de pensar, investigar e experimentar; coragem - para combater preconceitos e regimes opressivos; responsabilidade - por tudo o que fazemos ou deixamos de fazer.

\footnotetext{
${ }^{1}$ Hoje (outubro de 2019), o "núcleo duro" do grupo - pesquisadores da FAU-UnB - é composto de, além de Gabriela Tenorio e eu, Ana Paula Gurgel, Cláudia Garcia, Mônica Gondim, Liza Andrade, Rômulo Ribeiro, Valério de Medeiros e Vânia Loureiro. Constituem também o grupo nossos orientandos atuais de graduação e pós-graduação, assim como os egressos, que, neste caso, fazem parte do "DIMPU ampliado", muitos pertencentes a outras instituições de ensino, pesquisa e extensão, com quem mantemos contato. Até agora (outubro de 2019), o núcleo duro orientou 103 iniciações científicas, 60 mestrados e 22 doutorados. Como membros fundadores, ora pertencentes a outra instituição, em Brasília (UNIEURO), destaco Maria Elaine Kohlsdorf e Gunter Kohlsdorf: nós três lançamos as bases conceituais do "método DIMPU".
} 
Podemos, no entanto, refletir com José "Pepe" Mujica² quando saca sua afiadíssima "navalha de Ockham"3 e expressa as noções envolvidas em duas palavras: altruísmo e egoísmo, as quais, com todo o respeito a "Pepe", substituo pelas correlatas inclusão e exclusão. São "palavras guarda-chuvas" que tudo abarcam nas relações sociais, inclusive no que toca ao usufruto dos lugares de nossas vidas. A história da arquitetura desde sempre, inclusive a de Brasília, é também a do embate entre inclusão e exclusão.

Revisito a cidade a partir dessas ideias, adotando como pressuposto que ela, como qualquer outro sítio habitado na história, é eivada de interesses contraditórios e de conflitos decorrentes deles que uma visão maniqueísta não dá conta de entender. Em quase todos os lugares da capital, há rastros de inclusão tanto quanto de exclusão. Finalmente, ilustro como o olhar informa a prática pedagógica de ensino de projeto de urbanismo e como o ensino, à sua vez, rebate-se nas práticas urbanísticas na cidade: os "alunos" são os da graduação, alguns pertencentes aos quadros do governo local ainda como estagiários e constituindo o corpo de profissionais depois de formados, contribuindo para uma mudança de postura com relação à arquitetura da cidade.

\section{Os paradigmas}

Há autores para quem Brasília é tão excludente que negaria a todos o que de melhor as cidades brasileiras ou não - são ao longo da história. James Holston talvez melhor represente a vertente:

Em Brasília, o público dos espaços abertos em outras cidades brasileiras simplesmente desapareceu. [...] A vida social oscila, sem salvação, entre o trabalho e a residência. [...] a esmagadora sensação de monotonia e tristeza que os brasilienses experimentam da cidade. (Holston, 1993, p. 312, 170 e 158, respectivamente).

Nessas narrativas, Brasília seria uma distopia a mais, porém o pesadelo tornado real. Mas não é. Contudo, Holston toca no aspecto que interessa aqui em primeiro plano: as relações entre a arquitetura da cidade e os modos de apropriação dos seus lugares, dimensão também abordada por outros autores, como Rykwert (2000), que acentua a falta de urbanidade da cidade provocada pelo uso especializado do solo em setores como bancário, hoteleiro, hospitalar, comercial etc. Outros expoentes da teoria e da história da arquitetura moderna criticaram a cidade do ponto de vista estético, como Zevi ("a monumentalidade é incabível no projeto moderno"), Tafuri (Brasília nasce de "intenções demagógicas [...] guiada por um plano alegórico infantil que tenta reinterpretar um modelo urbano já experimentado na União Soviética dos anos 1930") e Frampton ("formalismo decadente") (apud Zein, 2001). Esse tipo de discurso falha por: 1) desrespeito à evidência empírica que uma observação mais rigorosa da cidade faculta; 2) precária atenção à história, ao ignorar o prestígio que o "monumental" disfruta no tempo.

As práticas humanas - incluindo o projeto e a produção de lugares - constituem um círculo virtuoso, na expressão de Anthony Giddens: aprendemos com nossos erros, com resultados que foram diferentes, aquém dos esperados ou além deles, e reconsideramos os pressupostos. A intervenção na realidade mediante projeto é assim: o círculo virtuoso da Figura 1 reúne Giddens (1984) e Hillier (1996), deste último incorporando o conceito de projeto como processo de conjectura-teste. Não foi diferente com Lucio Costa. Ficher \& Palazzo (2009) propuseram uma leitura dos "paradigmas urbanísticos de Brasília" - as fontes teórico-práticas em que o projeto bebeu:

- A cidade monumental, organizada a partir de dois eixos principais que definem uma estrutura viária simétrica, e em cujo tecido se distinguem nitidamente os espaços de representação do poder, seja nacional, seja local;

\footnotetext{
2 Presidente da República Oriental do Uruguai entre 2010 e 2015.

${ }^{3}$ William de Ockham (1285-1347) foi um frade franciscano, filósofo, lógico e teólogo escolástico inglês, que defendeu o princípio da economia, parcimônia e simplicidade nas teorias científicas. Sua "navalha" cortava o que sobrava.
} 
- A cidade rodoviária, estruturada por uma trama regular e hierarquizada de vias especializadas de circulação, que se cruzam em níveis diferentes, articuladas por trevos rodoviários;

- A cidade funcional, com destinações específicas para suas diferentes partes, as quais recebem tratamentos também tipologicamente diferenciados;

- A cidade parque, caracterizada pela predominância de extensas áreas verdes e cujas edificações não obedecem ao regime do parcelamento tradicional em lotes;

- A cidade radiosa, organizada em grandes quarteirões e na qual impera a separação de pedestres e automóveis;

- A cidade central, a ser ampliada pelo acréscimo de novos núcleos distintos, as cidades-satélites.

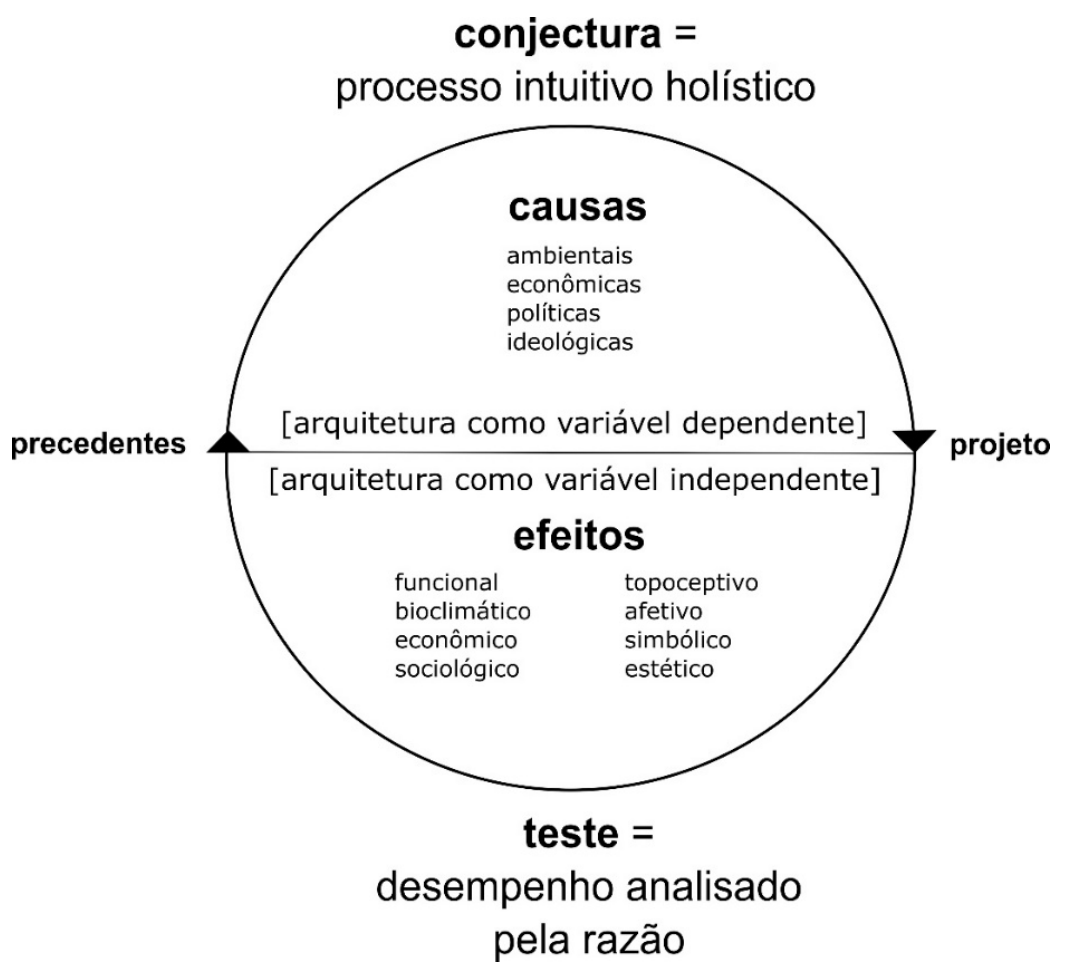

Figura 1 - Círculo virtuoso das práticas humanas. Fonte: Elaborada com base em Giddens (1984) e Hillier (1996).

A seguir, aproveito seus paradigmas como "gancho", faço uma leitura pessoal deles ao comentar os itens aproximadamente em ordem cronológica da precedência sobre Brasília, modifico sua ordem, acrescento um e elimino outro em prol da economia da argumentação.

\section{A cidade monumental}

Na cidade monumental, não são apenas os eixos ou os espaços que definem a monumentalidade; a própria cidade é um "monumento", se por tal entendemos lugares que marcam, ao isolar no território a dimensão superestrutural da ordem social: são formas construídas e artifícios diversos que as isolam do entorno, que visam à reprodução dos capitais político, ideológico ou cultural das capas dominantes. Denomino-as espaços de exceção (Holanda, 2018): Brasília é especializada para as funções de Estado no nível federal - uma cidade administrativa - e como tal replica a tradição de assentamentos tão díspares no espaço e no tempo quanto centros cerimoniais da cultura maia clássica pré-Colombo, kraals da cultura zulu da África pré-colonial, castelos feudais franceses, a Cidade proibida, de Beijing. Ela é, pois, excludente a começar pela escala do território nacional - a capital administrativa contraposta às cidades multifuncionais do resto do país. 
Nos exemplos históricos, distintos empiricamente, mas a compartilhar as mesmas características estruturais, têm morada somente "seres superestruturais" - classes sociais quase exclusivamente "simbólicas", vinculadas à política ou à cerimônia. Entretanto, como as capas sociais superiores não podem dispensar os trabalhadores manuais, seus serviçais de mais baixa formação (estavam até na Cidade proibida de Beijing), tampouco acontece aqui. Porém, não tiveram guarida no Plano Piloto e foram trasladados para além dos divisores de águas da bacia do lago Paranoá. A reprodução da vida material, secular, desses trabalhadores (exceções de praxe serão comentadas) dá-se a dezenas de quilômetros do coração metropolitano.

A "exceção" da capital ante o território nacional replica-se no Plano Piloto, este como parte da municipalidade maior onde está inserido, e nos espaços "monumentais" do próprio Plano Piloto diante das demais partes do projeto: a Esplanada dos Ministérios e a Praça dos Três Poderes contrastam com os demais setores centrais e com as áreas residenciais pelas formas construídas e pelos espaços livres que elas definem.

Os alunos visam borrar a clivagem em todos os níveis. No âmbito da municipalidade, por meio de: 1) mudança da natureza "puramente" secular e econômica dos núcleos dormitórios, fazendo-os abrigar também funções superestruturais, antes exclusivas do Plano Piloto - é exemplar o projeto para o Novo Centro Metropolitano de Alessandra Lessinger (Figura 2) (um projeto de conclusão de curso), em uma área intermediária entre os núcleos de Taguatinga, Ceilândia e Samambaia, a cerca de $30 \mathrm{~km}$ do Plano, hoje a somar cerca de 1 milhão de pessoas; 2) "secularizar" o Plano Piloto, ao se projetarem bairros dentro da área tombada ou imediatamente contíguos a ela, diversificados, em que todos caibam.

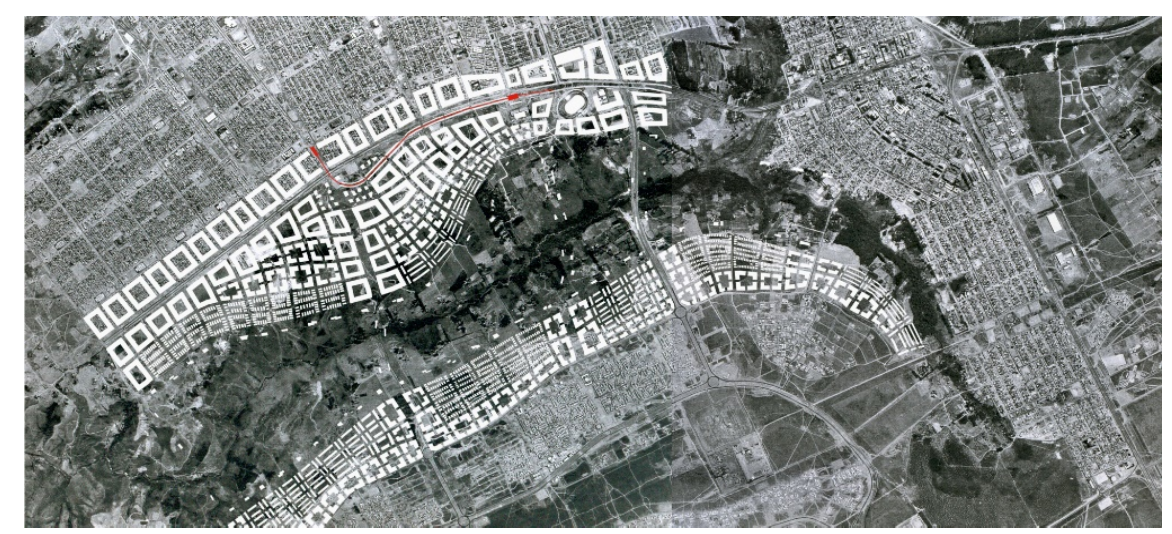

Figura 2 - Projeto para o novo Centro Metropolitano. Fonte: Alessandra Lessinger.

No âmbito do Plano Piloto, os alunos procuram borrar as fronteiras entre superestrutura e infraestrutura constituídas arquitetonicamente pelas relações entre o duplo Esplanada dos Ministérios/Praça dos Três Poderes, os demais setores centrais e as "asas" residenciais. Verdade, a dicotomia tem se suavizado no tempo: 1) serviços informais surgiram nas franjas da Esplanada dos Ministérios, cujos espaços são intensamente utilizados nos dias de semana, particularmente no horário do almoço (Figura 3); 2) a administração pública, assim como templos e outros equipamentos culturais, pontua as laterais das asas residenciais. Sem prejuízo de suas qualidades essenciais, pelo contrário, a Esplanada poder-se-ia inserir melhor na vida cotidiana da cidade, ser mais amigável com os habitantes no dia a dia, para o lazer ativo ou contemplativo, ou para uma happy hour em bares e restaurantes, que poderiam se consolidar nas suas laterais - como aliás foi esboçado pelo próprio Costa (1995) em seu projeto. Em sua tese de doutorado - Ao desocupado em cima da ponte -, Tenorio (2012) detectou os problemas a impedir o lugar de ter um bom desempenho como espaço para a vida pública, não só para abrigar os momentos de manifestação de massa, mas para ser confortável para os seus habitantes rotineiros. 


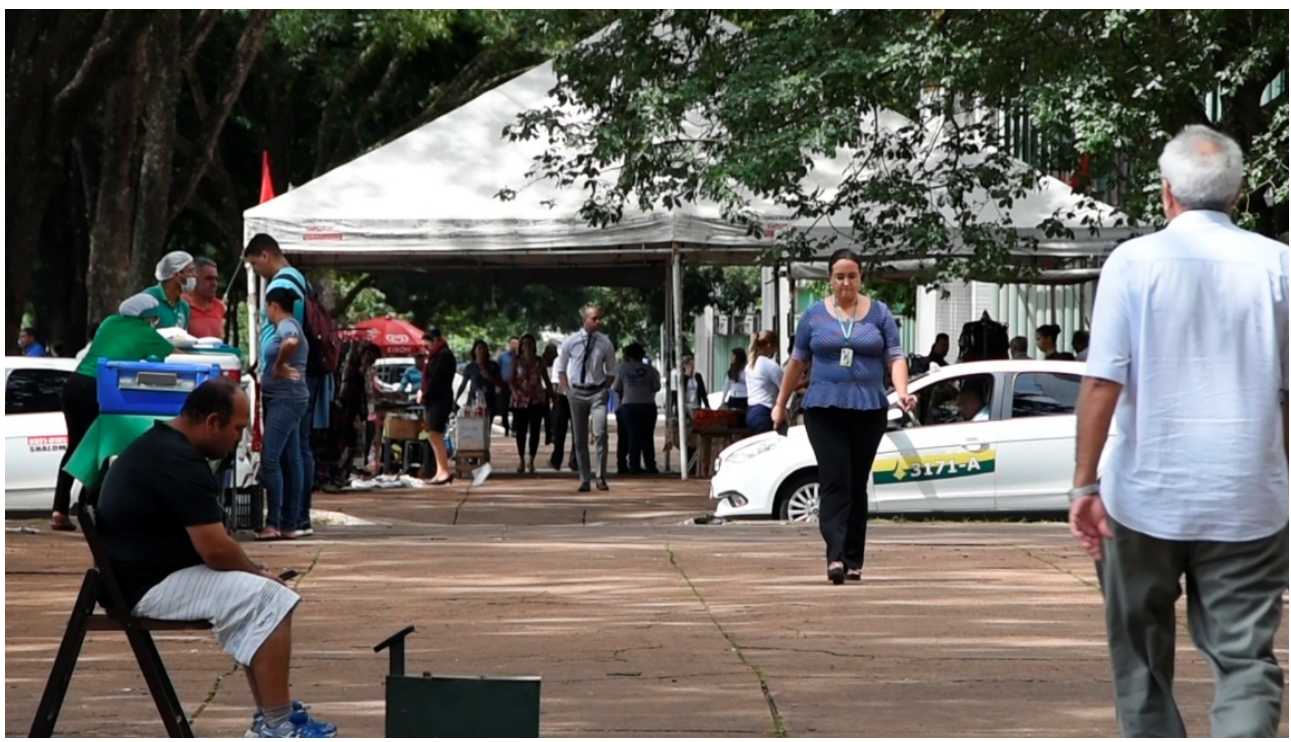

Figura 3 - Esplanada dos Ministérios, no horário do almoço de um dia rotineiro.

\section{A cidade central}

A tradição da cidade central - ou da cidade jardim - a ser ampliada por núcleos distintos e fisicamente separados tem origem no final do século XVIII, nas propostas dos chamados "socialistas utópicos".

"Teorias" antiurbanas são tão velhas quanto a consolidação da cidade industrial oitocentista. De Charles Fourier, com seu falanstério, em diante, tema a desdobrar-se em várias versões no século XIX, há o paradoxo do resgate da gemeinschaft ("comunidade") quando a gesellschaft ("sociedade") estava se fortalecendo, nas clássicas categorias de Ferdinand Tönnies (1887). Não são ideologias simplesmente conservadoras, são reacionárias: reagem às relações sociais contraditórias e conflituosas do capitalismo em formação, e que seriam acidamente criticadas por Marx enquanto "socialistas utópicas", cuja expressão talvez não seja muito feliz: não eram "socialistas" e tampouco "utópicas". É difícil ver na obsessão pelo controle dos corpos dos internos, no tempo e no espaço, típico desses assentamentos, algo a sugerir "socialismo". Por outro lado, a expansão por pequenos núcleos separados entre si no território desembocará futuramente nas garden cities de Ebenezer Howard, inspiração direta para o modo de expansão pensado para Brasília. Revela-se o horror ao grande tamanho, Louis Wirth caracterizará, junto com densidade e diversidade, como quintessência de cidade. Varrer a luta de classes para debaixo do tapete não poderia ficar mais explícito que no título do clássico de Howard em sua primeira edição: To-Morrow: A Peaceful Path to Real Reform, de 1898 (o negrito é meu). Curiosamente, "paz" sumiu do título da segunda edição, de 1902: Garden Cities of To-morrow...

A dispersão da população no território continua um mantra repetido por certas vertentes do urbanismo, a mais recente delas supostamente relacionada a questões ambientais. Entretanto, acumula-se a literatura em favor de cidades compactas (Rodgers \& Gumuchdjian, 2001; Bertaud, 2001). E, a propósito, eis uma história que testemunhei. Estava em Maringá (PR) em um seminário sobre urbanismo. Havia uma polêmica na cidade sobre as alturas máximas dos edifícios a serem permitidas pelo futuro Plano Diretor - os que defendiam prédios baixos, todos os andares passíveis de ser atingidos por escadas, e os que defendiam edifícios mais altos, de uns 20 pavimentos. Quando perguntado, o saudoso geógrafo brasileiro Aziz Ab’Saber começou observando: "vocês estão loucos!". Quando os defensores de edifícios baixinhos começaram a celebrar, ele se saiu com esta: "vamos começar a conversa a partir de 50 pavimentos". E diante da estupefação geral, emendou: "vocês têm um dos mais ricos solos do planeta, qualquer coisa menos que altíssimas densidades urbanas é crime". Nunca saberemos quanto de boutade havia nas palavras de Ab'Saber, mas uma coisa é certa: as fantasias da 
"cidade verde" ou da "cidade jardim" ruem como castelos de cartas diante de argumentos mais consistentes.

Os (re)fundadores - porque já existiu antes, conforme Hillier \& Hanson (1984) - deste genótipo 4 do horror ao unido, grande e diverso - quintessência da urbanidade - talvez não imaginassem que o pioneirismo de Fourier se desdobrasse em tantos fenótipos nos 200 anos seguintes: Robert Owen, Jean-Baptiste Godin, Victor Considérant, Ebenezer Howard, Raymond Unwin e Barry Parker, Clarence Stein e Henry Wright, Oscar Newman, Christopher Alexander, Le Corbusier, Lucio Costa... Mas não sejamos injustos com Mestre Lucio, sua "unidade de vizinhança" é heterodoxa, comentada no item cidade parque.

Disponibilizamos aos alunos literatura que questione a quase naturalização da (perversa) dispersão de Brasília. Rômulo Ribeiro (2008) complementa os estudos de Bertaud \& Malpezzi (1999) para 35 cidades dos cinco continentes, ao acrescentar as capitais brasileiras e suas áreas metropolitanas. Conceitua um "índice composto de qualidade de vida urbana" que inclui aspectos de configuração espacial, socioeconômico e ambiental urbano, e lança luz sobre o que leva Brasília a ser a segunda cidade mais dispersa do mundo, perdendo o lugar de honra apenas para Mumbai, na Índia. Por outro lado, Zechin (2014), utilizando-se de outro método (o centrográfico, advindo da Geografia), revela como as separações em Brasília penalizam sobremaneira os mais pobres: a distância média das residências das camadas de renda inferior ao centro urbano em Brasília $(25,8 \mathrm{~km})$ é muito maior que a de outras cidades brasileiras de tamanho aproximado - por exemplo, Fortaleza $(7,4 \mathrm{~km})$ e Belo Horizonte $(4,3 \mathrm{~km})$.

Mas, se os espaços livres intersticiais da metrópole são um problema, eles são igualmente um precioso recurso. Os alunos especulam com ocupações dos tipos: 1) ao longo de corredores de transportes; 2) em áreas livres, sem importância ambiental ou expressiva, que podem abrigar ainda, dentro do perímetro tombado ou na periferia imediata dele, centenas de milhares de pessoas.

No primeiro caso, a ocupação ao longo das vias expressas que ligam o Plano às periferias distantes diminuiria uma imensa ociosidade infraestrutural: dezenas de quilômetros de estradas, tubulações de água e esgoto, linhas de eletricidade e telefone passam ao longo de terra de ninguém, sem "servidões" que elas alimentem. Isso implica imenso impacto ambiental (ignorado pelos defensores da cidade "polinucleada") apenas em função desses elementos, sem moradia ou outras ocupações urbanas que a eles correspondam (Mancini, 2008).

No segundo caso, o novo bairro Noroeste, em implantação a oeste da Asa Norte do Plano Piloto, está previsto para 40 mil habitantes, projetado por Paulo Zimbres Arquitetos Associados (a Figura 4 mostra os locais referidos neste texto, e a Figura 5, o projeto de Zimbres para o bairro Noroeste). Solução alternativa proposta pelos alunos Reinaldo Germano e colegas (Figura 6) poderia abrigar 120 mil habitantes, mais da metade da população do Plano Piloto hoje. As mais importantes diferenças entre os projetos são: 1) o dos estudantes ocupa porção muito maior da área disponível; 2) ele está articulado com as principais vias do entorno; 3) ele está composto de quarteirões, não por superquadras de esquema viário "em árvore", como nas tradicionais.

Na ponta oeste do Eixo Monumental, fala-se em um futuro "bairro Oeste": ouvimos na mídia a intenção governamental de construir ali mais um "bairro de classe média". É um sítio anteriormente usado com pátio de manobra ferroviária (lembra a Barcelona de Bohigas?), uma área degradada de $4 \mathrm{~km}^{2}$ que "implora" pela ocupação, não pela "classe média", mas por todas as classes sociais, ademais abrigando administração pública, comércio e serviço, um pedaço de verdadeira "cidade"; simulações mostram que poderíamos chegar facilmente a 100 mil moradores. Os dois bairros juntos - o Noroeste e o Oeste somariam praticamente a população do Plano Piloto atual.

\footnotetext{
${ }^{4}$ Conceito da Biologia importado para a Arquitetura por Hillier e Hanson (1984): uma mesma estrutura abstrata subjacente a uma diversidade de manifestações empíricas.
} 


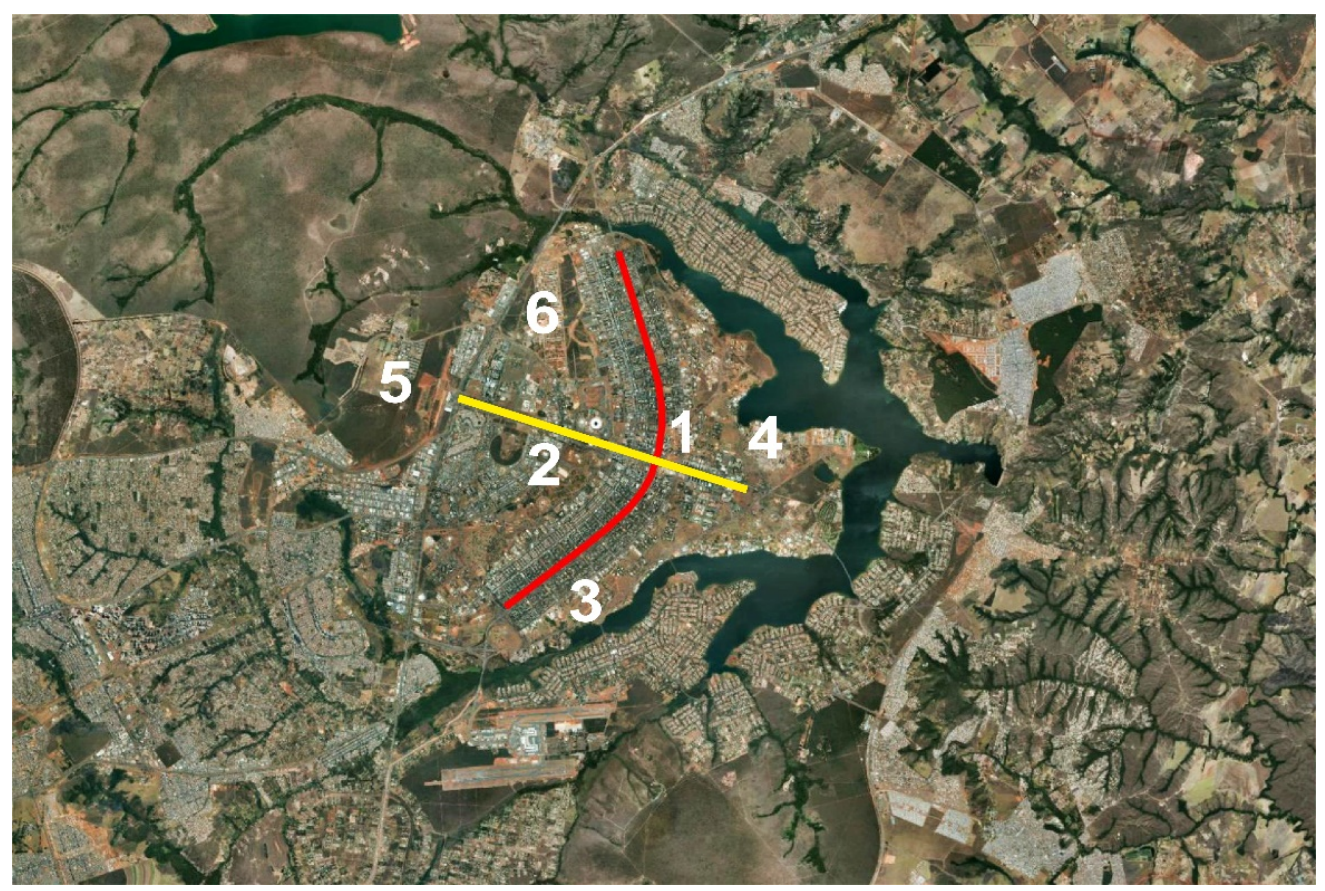

Figura 4 - Locais referidos neste texto: (1) Plataforma Rodoviária, no cruzamento dos dois eixos estruturadores da cidade; (2) Eixo Monumental (amarelo); (3) Eixo Rodoviário (vermelho); (4) Vila Planalto; (5) Potencial bairro Oeste; (6) Bairro Noroeste.

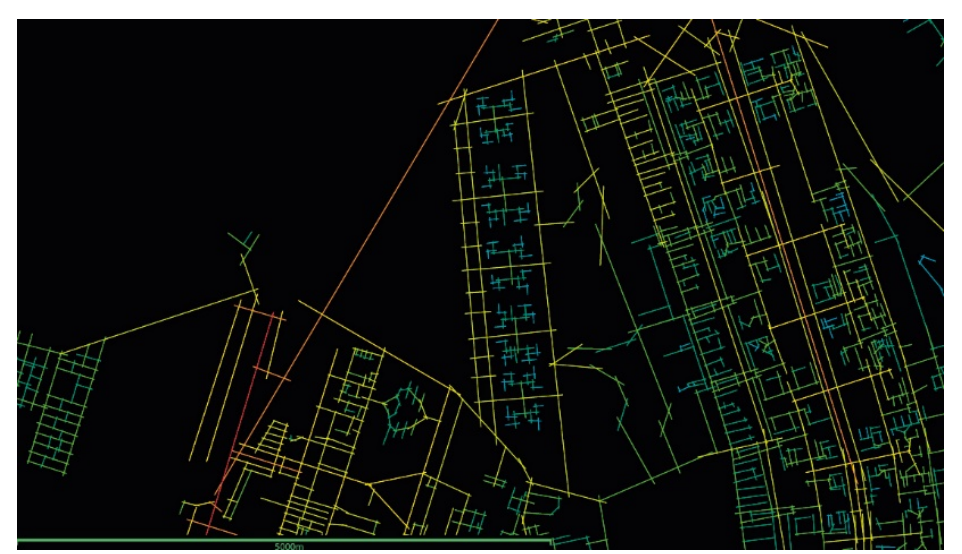

Figura 5 - Esqueleto viário para o novo bairro Noroeste, projetado por Paulo Zimbres Arquitetos Associados (no centro da imagem).

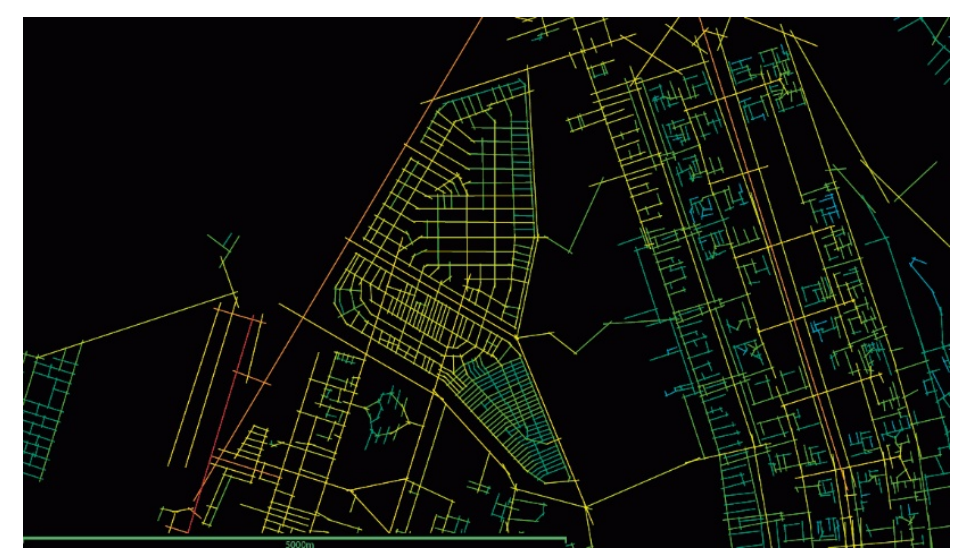

Figura 6 - Esqueleto viário para o novo bairro Noroeste, projetado por Reinaldo Germano e colegas (no centro da imagem). 


\section{A cidade rodoviária}

A cidade rodoviária, com sua especialização viária, supostamente resolveria bem a circulação de veículos e pedestres. Em Brasília, é um mito. A caminhabilidade é relativamente bem resolvida nas superquadras (mesmo aqui abundam barreiras); fora delas, toda prioridade é para os veículos automotores. 0 "Eixão da Morte" (imagine a razão do apelido) é uma via expressa que cruza a cidade de norte a sul em que os veículos trafegam ininterruptamente a $80 \mathrm{~km} / \mathrm{h}$, criando uma barreira metálica a dividir a cidade em "Brasília Oriental" e "Brasília Ocidental" (Figura 7). Aos pedestres restam desconfortáveis, infectas e inseguras passagens subterrâneas, separadas entre si por mais de $500 \mathrm{~m}$ (por essas razões, e apesar do perigo, cerca de 30\% dos que cruzam o Eixão o fazem temerariamente na superfície, driblando os carros) (Holanda, 2015). A exclusão do usufruto da cidade, aqui, é a dos caminhantes. Sim, o "paradigma" rodoviário é uma das inspirações de Lucio Costa; não, o paradigma não pode ser alçado a uma característica essencial da cidade a ser preservada como patrimônio cultural da humanidade, pois ela foi tombada em função do sábio jogo de "escalas" (ou tipos morfológicos - o monumental, o gregário, o residencial e o bucólico) que Lucio Costa empregou em seu projeto.

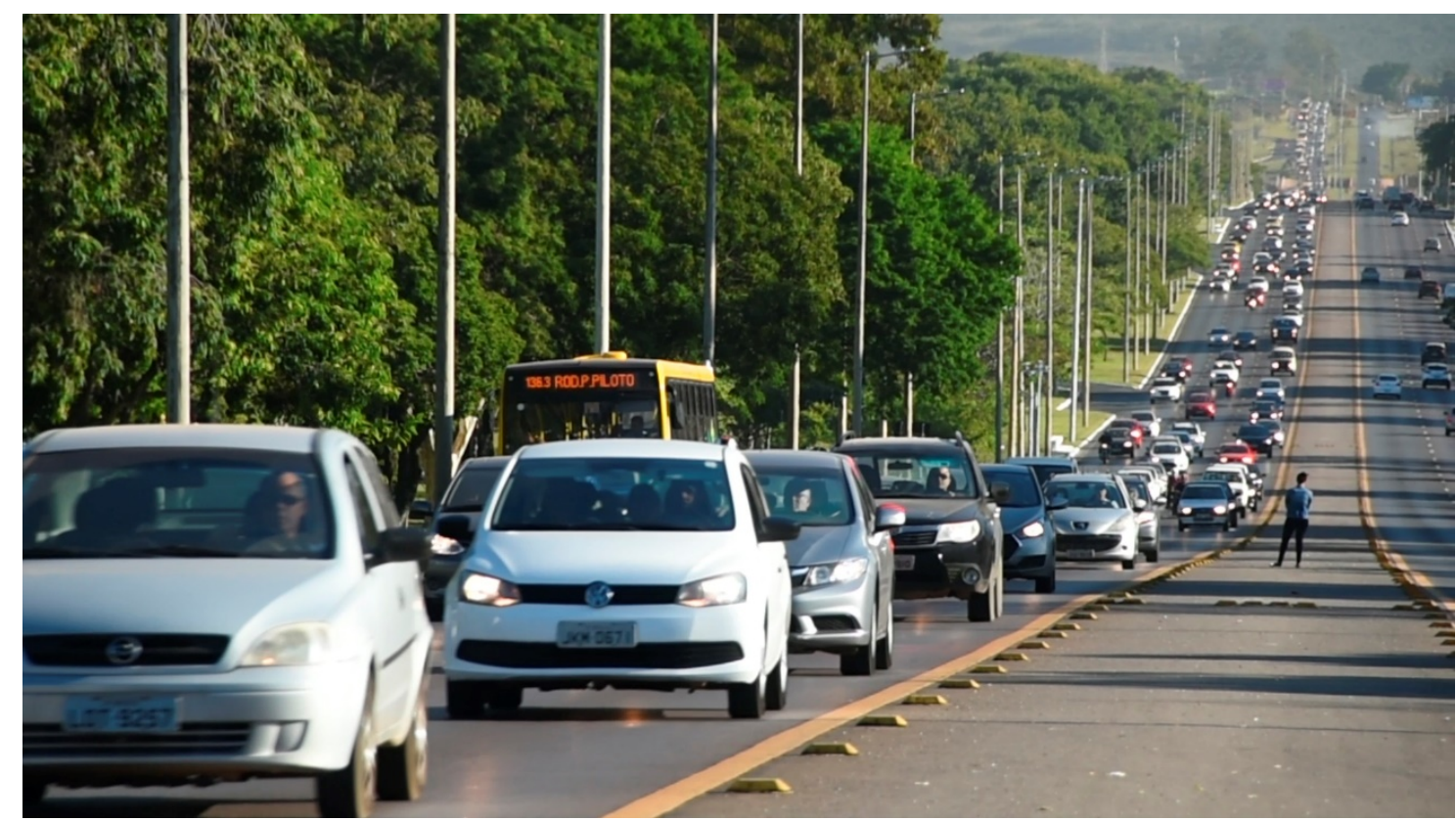

Figura 7 - Eixo Rodoviário em um dia de semana, hora de pico matinal.

A cada novo acidente fatal (é uma das vias mais perigosas de Brasília), ressurge o debate sobre o que fazer com o Eixão. Propostas cosméticas ou equivocadas abundam: melhorar as rampas das passagens subterrâneas, melhorar a sinalização, colocar segurança 24 horas, colocar comércio ao longo delas (ninguém "combinou com os adversários", no dizer jocoso do saudoso Garrincha: qual o comerciante insano que vai se instalar em lugar de fluxo de pedestres tão fraco e concentrado apenas nos horários de pico?!), e, pasme: colocar um muro de concreto no meio da via para impedir que os pedestres se aventurem a atravessá-la - a analogia com Berlim ficaria agora perfeita.

Temos especulado com alternativas diversas para o lugar. Em cooperação com a então aluna Eduarda Aun, simulamos em 2015 uma configuração a dar aos caminhantes o direito de cruzá-lo na superfície, em faixas de pedestres, em uma avenida semaforizada, com tecnologia de ondas verdes a controlar o fluxo veicular descontínuo em velocidade máxima de $60 \mathrm{~km} / \mathrm{h}$, canteiro central arborizado, mobiliário urbano de apoio para descanso etc. (Figura 8). 


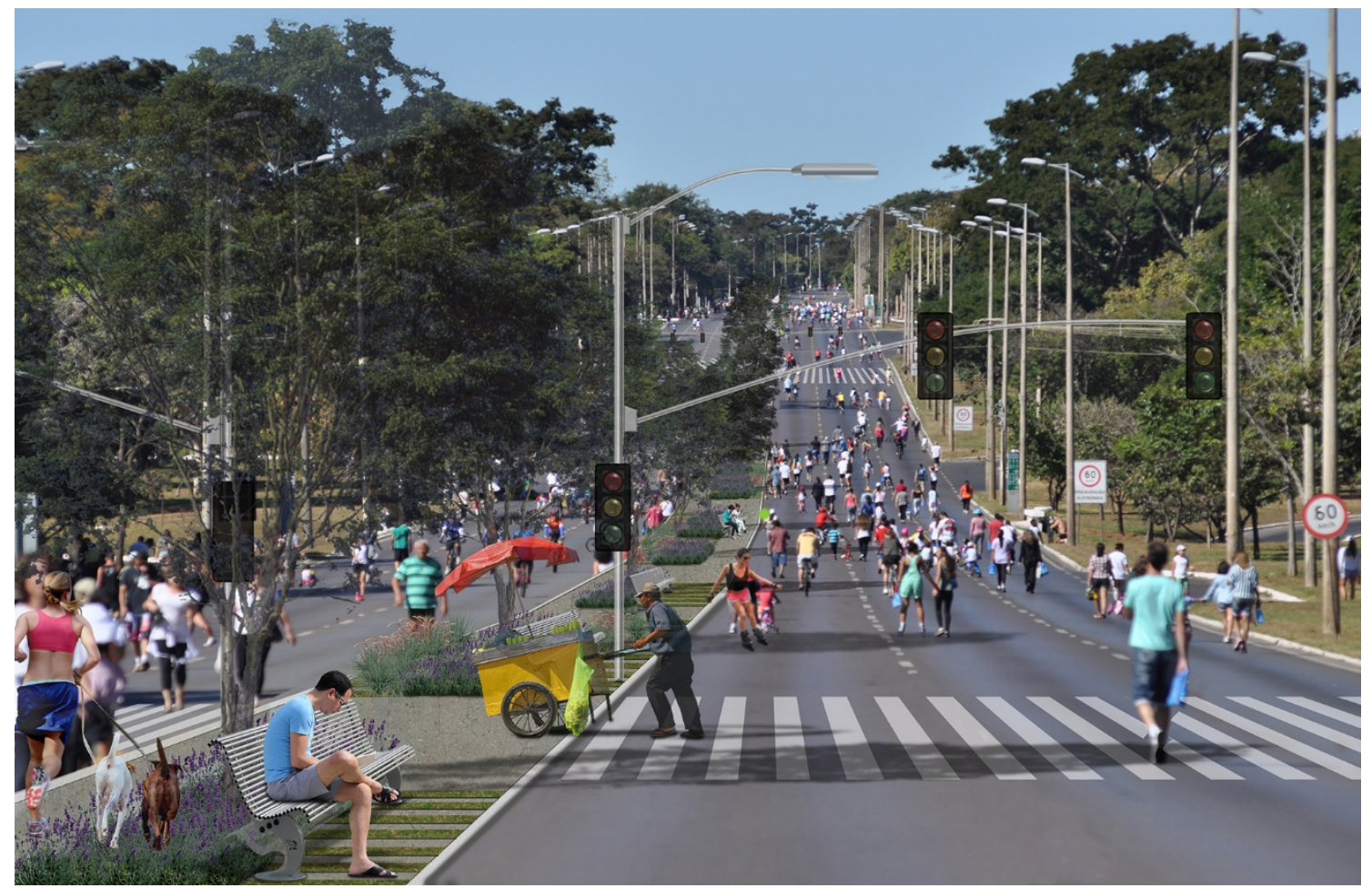

Figura 8 - Simulação de um possível futuro Eixo Rodoviário. Fonte: Frederico de Holanda e Eduarda Aun.

Tais ideias não desvalorizariam o Eixão como elemento estruturador fundamental da cidade; pelo contrário, fortaleceriam sua presença, prática e imageticamente, nos corpos e nas mentes dos habitantes. Sua importância na cidade é ilustrada pelo "Eixão do Lazer" (Figura 9): aos domingos e feriados, ele seria fechado aos veículos e aberto à franca apropriação das pessoas; centenas delas, de todas as idades, ao longo dos seus $12,4 \mathrm{~km}$ de extensão, andariam de bicicleta, de triciclo, caminhariam, correriam, patinariam, poderiam se encontrar, conversariam, ouviriam música de bandas que se apresentariam, sentariam nas mesinhas em suas franjas, estenderiam mantas e fariam piqueniques sentadas no gramado ou nele deitariam para relaxar, comprariam itens de artesanato, crianças pequenas brincariam em uma variedade de aparelhos montados em áreas sombreadas etc. 


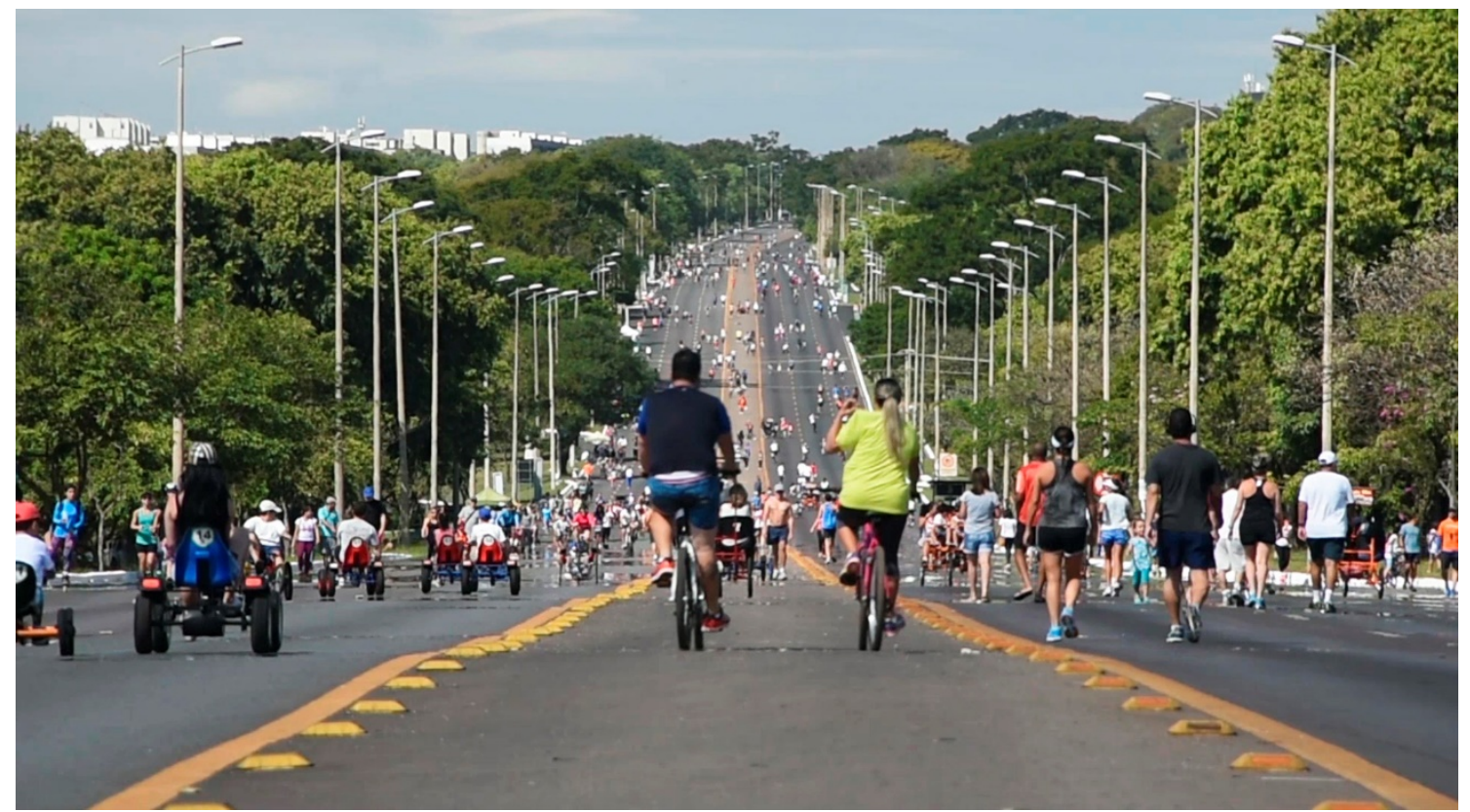

Figura 9 - "Eixão do Lazer", fechado aos veículos nos domingos e feriados.

\section{A cidade funcional}

A cidade funcional, com setores que correspondem a usos específicos - hospitalar, bancário, hoteleiro, comercial etc. - reflete-se em um âmbito público em que não vemos intensidade, continuidade e diversidade de presença social; um típico processo top-down ("de cima para baixo") presidiu a distribuição das atividades sobre o chão. Pouco restou às decisões individuais dos cerca de 3 milhões de sujeitos sociais da municipalidade (Brasil, 2019), muito limitados em sua capacidade de constituir a microeconomia que faz a riqueza das ruas das cidades pré-modernas.

Eppur si muove... Por mais top-down que tenha sido pensada uma cidade, há forças contínuas a pressionar por transformações em direções imprevistas: processos bottom-up ("de baixo para cima"), realizados por milhões de sujeitos sociais, configuram e reconfiguram continuamente a cidade (Tonkiss, 2013).

O paradoxo maior do projeto de Lucio Costa foi a Plataforma Rodoviária, uma superestrutura de quatro níveis que abriga o terminal dos ônibus urbanos, localizada no centro mesmo do Plano Piloto - e da metrópole. Em uma cidade pensada primordialmente para o carro - que passaria a ser "quase como um membro da família" (Costa, 1995) - rezando pelo paradigma rodoviário, é conferido lugar de honra o ponto de chegada do transporte coletivo. A fascinante estrutura que abriga a estação de ônibus está no cruzamento dos fundamentais elementos estruturadores da capital - o Eixo Rodoviário e o Eixo Monumental. Do deck superior da Plataforma em direção a leste, vislumbramos o principal cartão postal da cidade, a Esplanada dos Ministérios - e nos deslumbramos com ela (Figura 10). Do milhão de pessoas que descem para o Plano Piloto todos os dias para empregos ou serviços vindos dos núcleos satélites (Miragaya, 2013), dezenas de milhares passam pela Plataforma Rodoviária. É curioso Lucio Costa não ter se dado conta da dimensão profundamente inclusiva que seu projeto implicava, pois ele pensou a Plataforma

[...] como um centro requintado, igual a Champs Élysées ou Piccadilly Circus, uma coisa mais cosmopolita [e o povo dele se apropriou]: eles estão com a razão, eu é que estava errado. Eles tomaram conta daquilo que não foi concebido para eles. Foi uma Bastilha (Costa, 1985, p. 66; Costa, 1995, p. 311). 


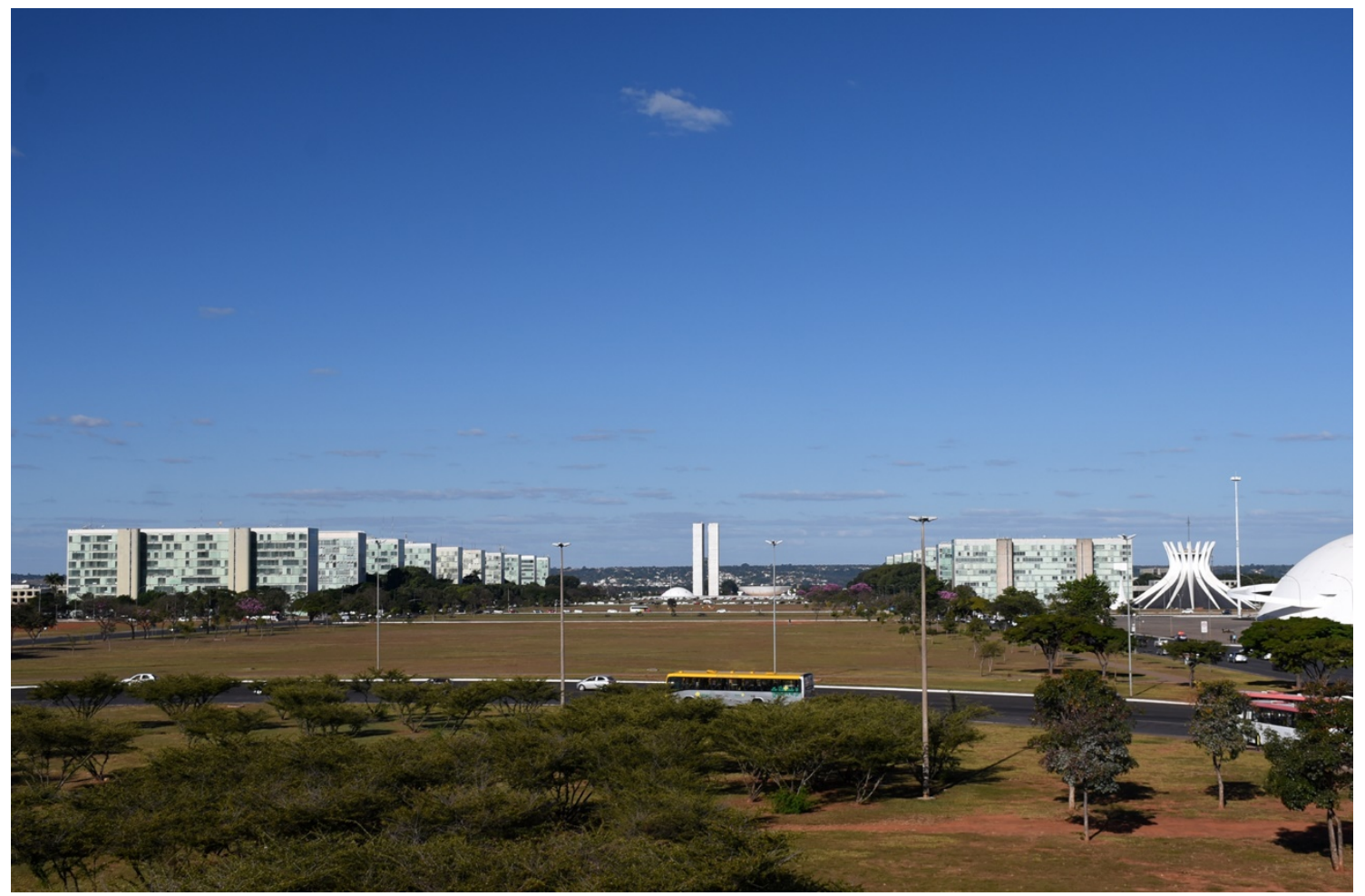

Figura 10 - Esplanada dos Ministérios, vista do deck superior da Plataforma Rodoviária.

Atualmente, a Plataforma faz transbordar para os setores ao redor - comerciais, bancários, hoteleiros e hospitalares - intensos fluxos de pedestres, mas estes deparam com fortes descontinuidades do tecido urbano - diferenças de nível, parques de estacionamento e áreas verdes - com a respectiva ausência de fachadas ativas a implicar desconforto e carência de uma paisagem mais estimulante (Figura 11).

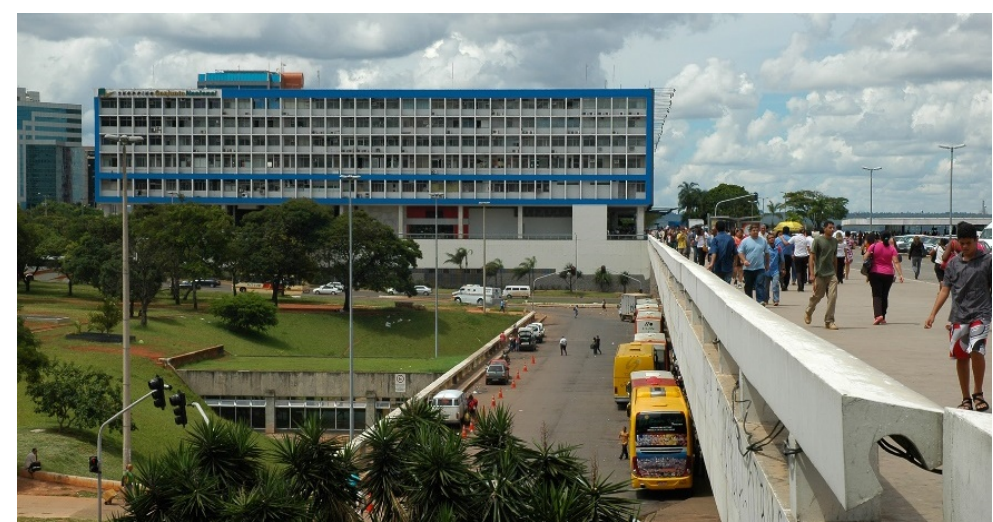

Figura 11 - Ausência de fachadas ativas por centenas de metros no coração da cidade. 


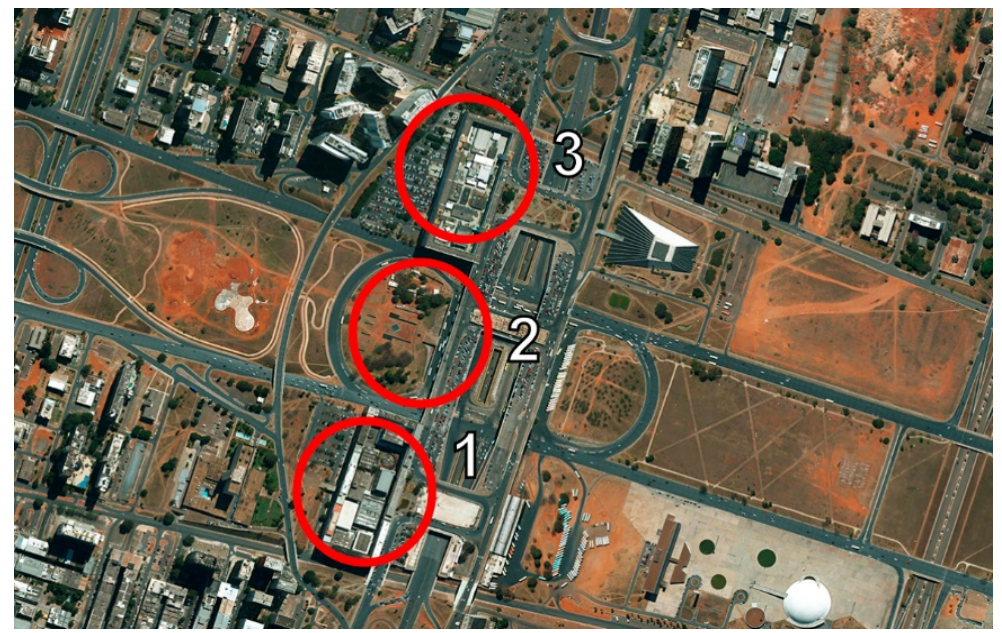

Figura 12 - (1) "CONIC", ou Setor de Diversões Sul; (2) Vazio correspondente ao que seria o "Setor de Diversões Central"; (3) "Conjunto Nacional", ou Setor de Diversões Norte.

Os alunos têm explorado uma "arquitetura de adições" (Pérez de Arce, 2015) ao se debruçarem sobre a área: novas edificações preencheriam vazios sem significação prática ou expressiva forte, e novas ligações intensificariam as relações entre os vários níveis topográficos da área central, contribuindo para que se diluísse seu caráter de "arquipélago", os setores que, além de monofuncionais, são separados entre si por barreiras físicas. Um dos mais incompreensíveis vazios está no coração da cidade, ao longo do deck superior da Plataforma Rodoviária pelo seu lado oeste, entre o Setor de Diversões Norte e o do Sul (Figura 11 e Figura 12).

Outrossim, a intensificação de ligações com o entorno tem passado, inclusive, pela proposta de um VLT (ou um monotrilho) a conectar o deck superior da Plataforma com a rampa gramada para a Torre de TV, a oeste, e a Esplanada, a leste, como no projeto de Daniel Dubugras enquanto estudante (Figura 13). O VLT conectaria o terminal de ônibus e a estação de metrô à maior concentração de empregos da cidade, a leste e a oeste da Plataforma.

O conjunto Plataforma Rodoviária mais setores vizinhos (Setor de Diversões Norte e Setor de Diversões Sul, além do não construído "Central”) quiçá seja o lugar mais inclusivo da metrópole. Decerto é a classe trabalhadora que mormente ocupa o nível térreo da Rodoviária, a esperar pelo transporte, comer um pastel com caldo de cana em um dos inúmeros quiosques (que delícia!), comprar quinquilharias, sentar nos bancos a conversar com amigos (Figura 14). No entanto, os complexos edificados debruçados sobre a Plataforma (conjuntos "Nacional" e "CONIC") atraem outra faixa social, que, embora venha de carro e usufrua a generosa oferta de vagas para estacionamento, mistura-se nos corredores internos dos conjuntos e nas calçadas do entorno aos que desceram nos terminais de ônibus ou do metrô. Sim, há diferenças sociais entre o "CONIC", mais popular, e o "Nacional", mais elitista, e, neste, entre o nível do térreo (o da Plataforma) e os superiores, que abrigam lojas mais caras. É um exemplo de estratificação social, sim, mas em estabelecimentos muito próximos, cuja configuração faculta ao espaço público funcionar como "mecanismo misturador" (Peponis, 1989), favorecendo o encontro com a alteridade. 

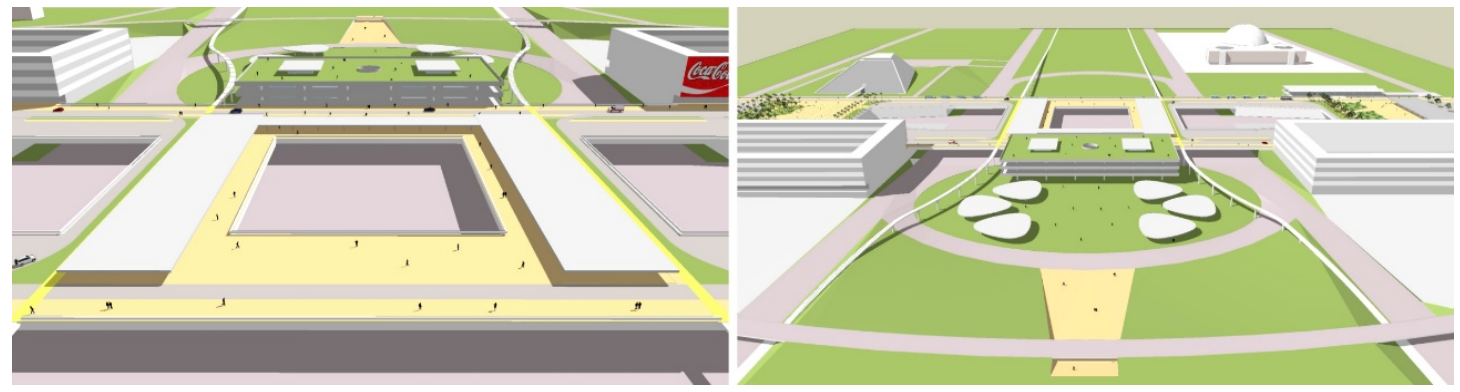

Figura 13 - "Arquitetura de adições" no centro de Brasília. Fonte: Daniel Dubugras.

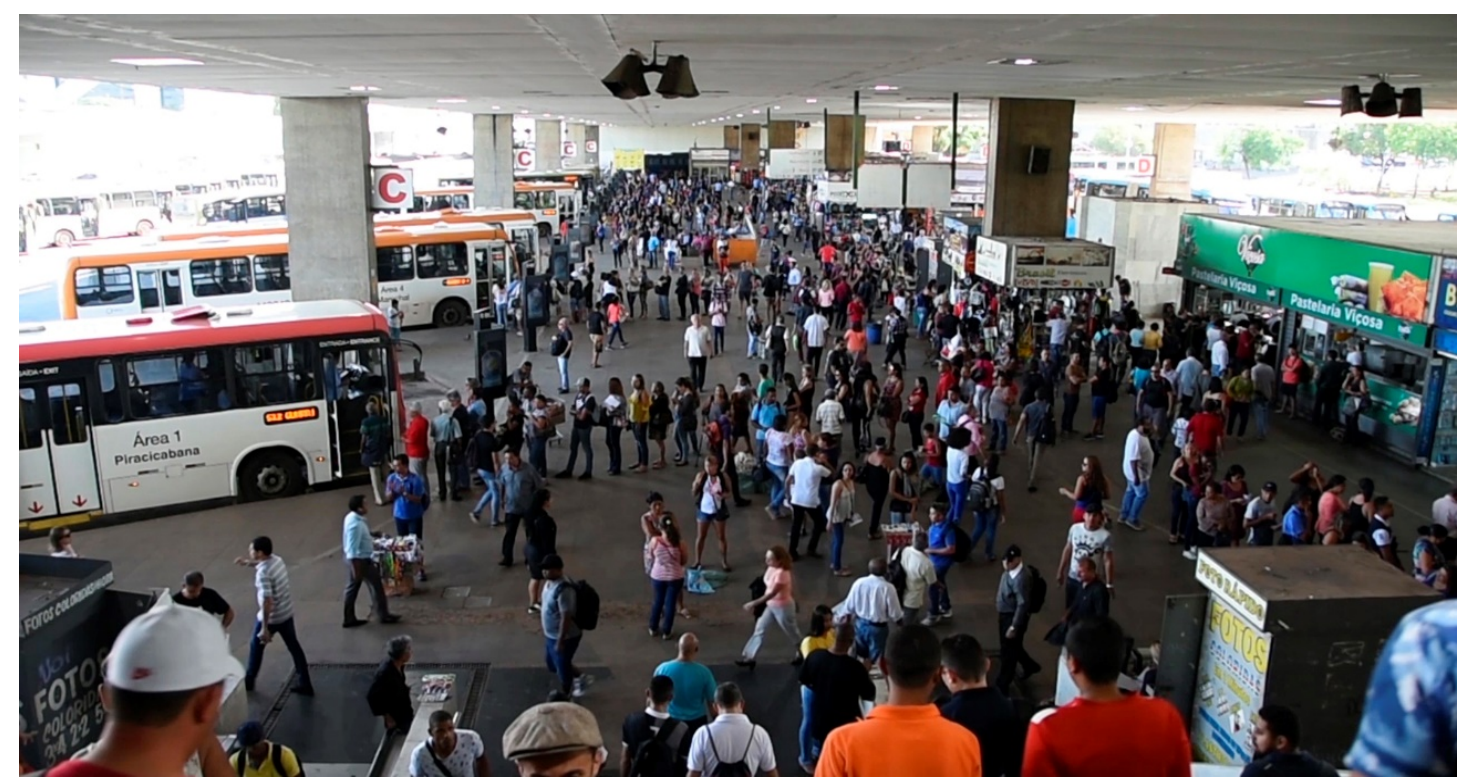

Figura 14 - Plataforma Rodoviária, nível térreo.

\section{A cidade universal}

Aqui adiciono um paradigma àqueles sugeridos por Ficher \& Palazzo (2009), o da cidade universal: necessidades humanas como contempladas pelo Movimento Moderno são idênticas para todos os seres humanos, naturalizadas em sua dimensão biológica - resumidas em sol, ar, luz, verdor... Por isso, Lucio Costa propôs um único tipo edilício em suas superquadras residenciais: apartamentos em blocos de ("talvez", como está nos seus textos) seis pavimentos sobre pilotis, com elevadores. 0 valor de mercado dos apartamentos - e respectivo acesso a eles por poderes aquisitivos variados - dar-se-ia em função de tamanho, acabamento, localização diferente dentro da quadra (houve uma concessão, uma excepcionalidade, as "casas individuais", residências especiais fora das superquadras residenciais, na margem do lago) ${ }^{5}$. Todavia, o tempo e nossas pesquisas (Holanda, 2015) mostraram que seu tipo universal é excludente, tem custos de produção e de manutenção incompatíveis com o poder aquisitivo da maioria da população. A esta restou ser alocada fora do projeto, e, na lógica da cidade jardim, a quilômetros de distância, para manter a "fisionomia" do projeto imaculada.

Uma cidade mais democrática, onde também nas áreas residenciais a visibilidade da alteridade acontecesse, é utopia delirante e ingênua? Não. Brasília tem o fascinante exemplo da Vila Planalto, sita a 1.500 m da Praça dos Três Poderes, remanescente de um acampamento de empreiteiras surgido em

\footnotetext{
${ }^{5} \mathrm{O}$ fato foi intuído nos primeiros momentos do desenvolvimento do Plano, o que resultou em uma quarta fileira de superquadras, inexistentes no projeto original, mais econômicas, de prédios de três pavimentos sobre pilotis (alguns, inclusive, sem eles), sem elevadores e sem garagem subterrânea. Nossas pesquisas confirmam que, sim, eles abrigaram uma população de poder aquisitivo significativamente menor que a das superquadras originalmente propostas.
} 
1957, localizado fora da área de inundação do lago Paranoá e inserido no perímetro tombado da Capital (1987) (aproximadamente a parte central da Figura 4). Há 20 anos, acompanhamos a estratificação social do lugar, primeiro pelos dados do Censo de 2000 (IBGE, 2002), depois pelos de 2010 (IBGE, 2011) e por levantamentos mais recentes. Sim, a Vila tem se transformado no tempo, mas Ocaranza Pacheco (2015) - enquanto mestrando e atual doutorando do nosso grupo - mostrou que a elitização tem se dado mais nos serviços que no perfil socioeconômico dos moradores. O lugar tem se consolidado como um polo gastronômico, mas, entre 2000 e 2010, quanto aos habitantes, seu perfil se tornou mais popular, e não menos. A Vila tem quase precisamente a mesma estratificação social da metrópole brasiliense como um todo - famílias de diferentes poderes aquisitivos, morando, sim, em diferentes casas, lotes, quadras, ruas, mas constituindo um bairro contínuo. A variedade edilícia e urbana determina (não receio o verbo) a variedade social: mantendo-se a configuração do lugar - esse é o ponto -, manter-se-ão os padrões correntes de valorização imobiliária diferenciada, que existem há mais de 60 anos e que permanecerão enquanto durar a atual configuração. A variedade edilícia tem que ser muito mais ampla que tamanho dos imóveis, acabamento e localização, como pensou Lucio Costa. $\mathrm{O}$ arquiteto não percebeu que, para abrigar todas as classes sociais, carecia de uma paisagem urbana muito mais diversificada que a de suas superquadras, que incluísse "casas individuais", passando pelos edifícios de apartamentos, de alturas variadas, com e sem elevadores, com e sem garagem subterrânea, com e sem pilotis, até lotes para autoconstrução de habitação de interesse social - em suma, tudo o que encontramos na cidade real maior. A variedade não estaria, pois, em manchas monotemáticas separadas por dezenas de quilômetros, e sim em bairros diversificados a abrigar todos os tipos arquitetônicos - e todas as gentes. Vislumbro o que seria um corte transversal de uma asa residencial a acalentar a variedade...

\section{A cidade parque}

Explicitamente, Lucio Costa denominou Brasília cidade parque. Ele abraçou uma das duas versões do Movimento Moderno na escala da cidade que Hillier \& Hanson (1984) denominam "dura" e "suave": a primeira investe na continuidade e densidade do tecido urbano, mas com uma proliferação de barreiras a resultar em esquemas labirínticos típicos de conjuntos habitacionais de interesse social; a segunda investe em distâncias, descontinuidades, dispersão. Em Brasília, a suavidade realiza-se por excelência nos espaços monumentais da cidade, nas superquadras residenciais e na "escala bucólica" - fartas áreas non aedificandi ao redor das áreas construídas do Plano, parques na orla do lago etc.; a dureza está nas "cidades"-satélites (aspas, porque são de fato bairros dormitórios), onde proliferam junções em "T" ou em "L", a prejudicar a orientabilidade por meio dos espaços - pela dificuldade de se perceber um todo constituído de partes relacionadas - e sua caminhabilidade - pelas maiores distâncias interpartes que isso implica. A suavidade também se realiza na escala maior da municipalidade, pelas distâncias internúcleos urbanos. Hillier e Hanson argumentam que uma e outra são danosas à apropriação dos espaços públicos. Contudo, a solução de Costa é tão peculiar, tão diferente de tudo que se produziu antes, que é injusto equacioná-la aos conceitos tradicionais de "unidade de vizinhança", às soluções das cidades jardins ingleses, mais ainda às unités d'habitación de Le Corbusier - são edifícios três vezes mais altos.

A característica distintiva do espaço residencial do Plano são as "superquadras" (Figura 15). É a unidade urbana básica, algo equivalente ao quarteirão urbano tradicional, embora maior (daí o "super"), uma área que mede cerca de $250 \mathrm{~m}$ por $250 \mathrm{~m}$, considerando os limites definidos pela calçada de pedestres periférica. Quatro fileiras de tais unidades localizam-se a leste e oeste do Eixo Rodoviário. Além dos blocos residenciais referidos, há o jardim de infância, a escola para os seis primeiros anos do Ciclo Educacional Fundamental e uma banca de jornal. 0 resto é espaço público aberto, incluindo um playground e uma quadra esportiva multifuncional. Ao todo, os volumes construídos ocupam cerca de $15 \%$ da área, enquanto em tecidos urbanos pré-modernos os lotes cercados mais eventuais prédios isolados geralmente ultrapassam os 50\% (na Planaltina do século XIX, por exemplo, tornada um núcleo satélite com a construção de Brasília, chegavam a 68\%). 


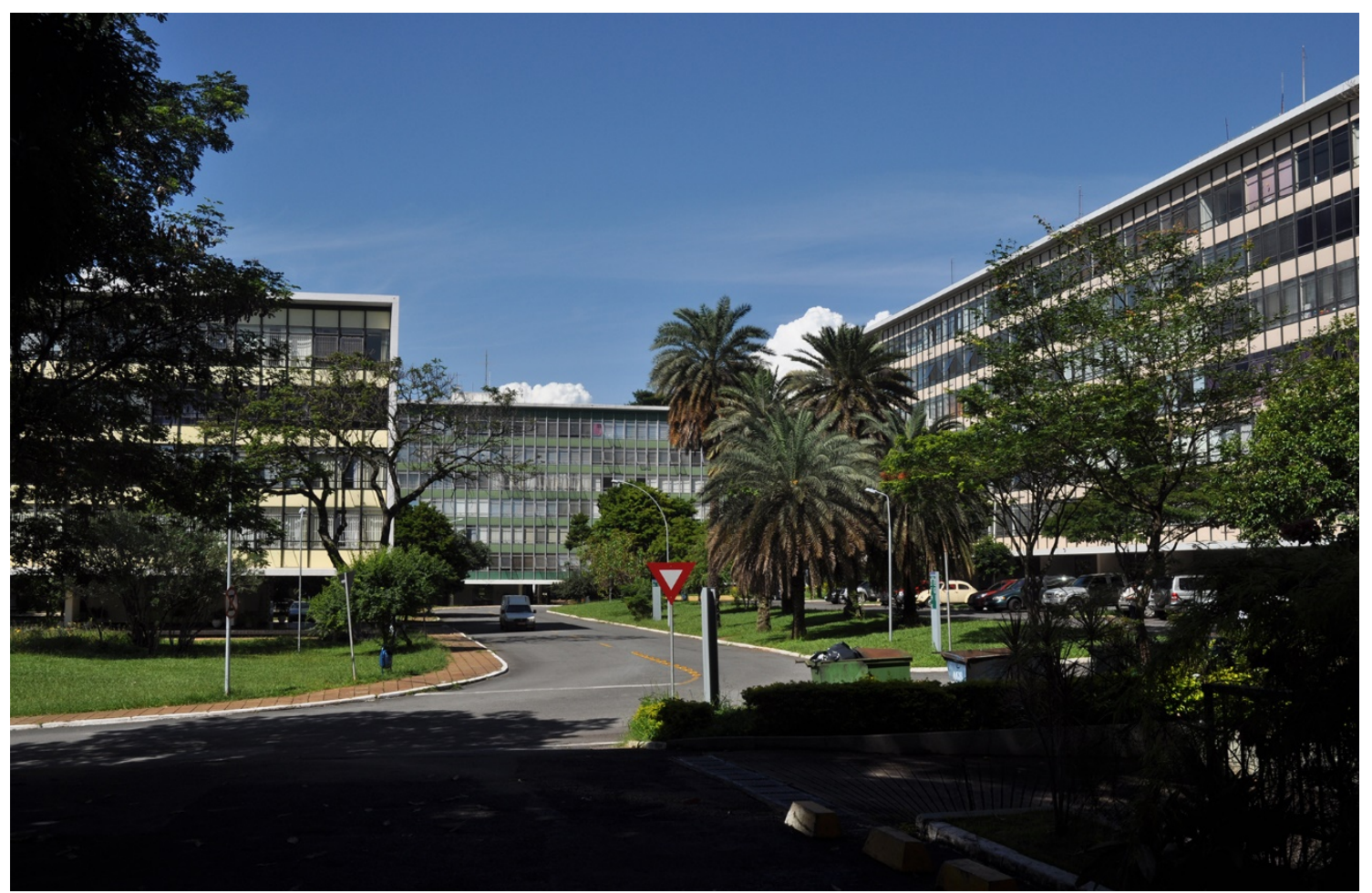

Figura 15 - Superquadra Sul 308, talvez a mais bem-sucedida delas.

No entanto, há sempre pessoas paradas ou em movimento, cujo número e variedade mudam ao longo das horas do dia e dos dias da semana: crianças pequenas brincam em caixas de areia, nos playgrounds, usam o campo de jogos, acompanhadas por pais ou babás; adolescentes sentam-se em grupos para conversar; jovens e adultos fazem caminhadas, jogam nas quadras poliesportivas ou participam de sessões de Tai Chi no início da manhã; idosos se exercitam em aparelhos próprios à terceira idade; grupos se reúnem em mesas e cadeiras em áreas sombreadas para jogar baralho ou dominó; famílias ou grupos de amigos fazem uma refeição noturna em restaurantes improvisados ao ar livre, apoiados por food trucks, que ocupam vagas de estacionamento, vazias à noite; feiras peripatéticas - certo dia da semana para certa superquadra - vendem comida ou artesanato; a banca de revistas é ponto de encontro...

Os estudantes, particularmente os que aqui nasceram e cresceram, estranham o discurso demonizador das superquadras: os nativos nada enxergam dos atributos perversos, simplesmente porque... eles não existem. Todos se deleitam com a paisagem, a tranquilidade, a beleza dos jardins, os atributos variados de sol/sombra, sons/silêncio, flores, aromas, temperatura do ar na zona de conforto de nossos corpos durante quase o ano todo... Está tudo implicado na sensação prazerosa relatada por residentes e visitantes ao serem atraídos para os espaços públicos. Versão suave, de fato, mas estamos longe, por um lado, das banais cidades novas inglesas, de densidades muito mais baixas e com proliferação de descontinuidades físicas, e, por outro, das gigantescas unités d'habitación de Le Corbusier, cerca de três vezes mais altas que os prédios das superquadras, perdidas no nada. Lucio Costa concebeu outra escala.

Todavia, como tudo pode ser melhorado (o círculo virtuoso de Giddens), incentivamos os estudantes a aperfeiçoar a "experiência superquadra". A legibilidade de Brasília é forte na escala do todo - particularmente na emblemática área monumental -, mas peca pela redundância na escala menor, ao longo das asas residenciais (Kohlsdorf, 1996) ${ }^{6}$. Entre os pontos a considerar estão: 1) melhor diferenciação espacial pela qual se criem espaços maiores e menores que confiram maior legibilidade ao todo; 2) melhor localização para a Escola Classe e o Jardim de Infância, normalmente posicionados nos pontos mais distantes da

\footnotetext{
${ }^{6}$ Kohlsdorf \& Kohlsdorf (2017) publicaram, em 2017, um verdadeiro tratado sobre o desempenho morfológico dos lugares - "síntese de
} uma vida", como o referem. 
entrada e que, no entanto, servem a um público também externo; 3) eliminação da dicotomia "espaços nobres" (verdes, ajardinados) versus "espaços de serviço" (asfaltados, sem árvores, usados exclusivamente para a passagem e estacionamento de veículos) etc. Teremos, assim, o melhor dos dois mundos (Holanda \& Barcellos, 2011) 7 .

Finalmente, há, sim, algo da versão dura de Hillier e Hanson em Brasília, não só no layout de alguns núcleos satélites, mas no esqueleto da municipalidade de Brasília como um todo. Valério de Medeiros $(2006,2013)$ realizou um estudo comparativo de 164 cidades mundo afora e concluiu que há, sim, uma cidade brasileira típica: ela é excepcionalmente fragmentada; isso significando que os layouts de ruas tendem ao labirinto, embora com um centro mais regular, a coincidir com os núcleos fundadores - o "oásis no labirinto". Depois, Coelho (2017) corroborou Medeiros ao realizar o estudo mais completo da estrutura viária do Distrito Federal até o momento. A fragmentação, somada à dispersão e à baixa densidade (Ribeiro, 2008; Holanda et al., 2008), implica distâncias a percorrer maiores entre casa e trabalho que as de outras cidades brasileiras de tamanho similar, o que penaliza particularmente as famílias mais pobres (Zechin, 2014; Holanda, 2019).

\section{Conclusão}

O leitor saberá melhor se, ao perscrutar este texto, há uma especificidade nos estudos de morfologia urbana em Brasília. Arrisco que sim: grandes distâncias, enormes vazios, fortíssima estratificação socioespacial, por um lado; a "invenção da superquadra", os emblemáticos espaços monumentais, o fascinante duplo "sagrado/profano" Esplanada dos Ministérios versus Estação Rodoviária, a festa dominical no Eixão do Lazer, por outro, são únicos dessa cidade, no mínimo pelo grau em que ocorrem. Difícil ignorar os temas e deixar de alimentar o círculo virtuoso de nossas práticas com o resultado de nossas reflexões sobre eles.

Sobre as práticas, gratifica-nos saber que nossos estudantes de graduação são crescentemente solicitados a apresentar suas propostas a instâncias do Governo do Distrito Federal; deparando com a temática urbana nas disciplinas de Projeto de Urbanismo, também a abordam em trabalhos de conclusão de curso, lidando com questões de mobilidade (incluindo o tema tabu da semaforização do Eixão), uso do solo, expansões urbanas; passam a ocupar cargos no governo local e realizar, agora institucionalmente, projetos urbanos.

O impulso para a pesquisa vem também dos polos opostos em que tendem a se congregar os discursos sobre a cidade. Por um lado, uma distopia perversa; por outro, uma utopia frustrada: proposta para uma cidade democrática por excelência, não seria inclusiva pelo caráter da sociedade brasileira, excludente, que o impediu. São inúmeras as reflexões que assim caracterizam o projeto de Lucio Costa, das quais representativo, pela força expressiva, é o trecho do poema "Mesma mineira em Brasília", de João Cabral de Melo Neto (1968):

Aqui as horizontais descampinadas

farão o que os alpendres remansos,

alargando espaçoso o tempo do homem

de tempo atravancado e sem quandos.

Intuímos que a cidade real e tampouco seu projeto original não são uma coisa ou outra - são as duas. Podemos enxergar em Brasília características excludentes e podemos fazer o oposto: atributos da cidade, no projeto e na realidade consolidada no tempo, implicam inclusão de sujeitos sociais, e cada lugar a seu modo, na qualidade e na quantidade que seus atributos o facultam.

\footnotetext{
${ }^{7}$ Exploramos essas ideias no nosso projeto para a SQN 109, realizado em parceria com Vicente Barcellos, relatado em Holanda \& Barcellos (2011), ora em implantação. Para uma reflexão sobre a heterodoxia das superquadras, ver os colegas externos ao nosso grupo de pesquisa Ferreira \& Gorovitz (2009).
} 
A qualificação estética da cidade, parafraseando Garcia (2009), revela talvez a mais profunda e inovadora faceta do projeto de Lucio Costa, como ele foi corajoso ao remar contra a mainstream do Movimento Moderno e incluir a monumentalidade em seu projeto, que, por excelência, distingue-o de todas as demais propostas do concurso.

A força expressivo-simbólica do lugar é universalmente inclusiva: Lucio Costa resgata da história dos assentamentos humanos a estética do sublime, que desde sempre nos fascina. Tradicionalmente, a categoria tem sido aplicada a sítios naturais grandiosos, a razão para o encantamento comentada por Botton (2003, p. 180-182):

Essa lição está escrita nas pedras do deserto e nos campos de gelo dos polos. E está escrita em termos tão grandiosos que nos podemos afastar desses lugares, não arrasados, mas inspirados pelo que está além de nós, privilegiados por nos submetermos a exigências tão majestosas. A noção de assombro pode até acabar se transformando gradualmente num desejo de culto.

Costa (1995) não recusou o grand design, perseguiu essa "noção de assombro" e ombreou seu projeto a lugares seculares ou milenares, como a Avenida dos Mortos (Teotihuacán, atual México, início no século III a.C.), A cidade proibida (Beijing, século XV), Champs-Élysées (Paris, século XVII), a Praça de São Pedro (Roma, século XVII), The Mall (Washington, século XVIII)... Não admira Brasília estar se consolidando como destino de peregrinação turística.

Na canção A dónde van... Silvio Rodríguez pergunta:

¿Adónde va la sorpresa,

casi cotidiana del atardecer?

De volta para casa, esteja onde estiver, faço sempre um caminho que passa pela Esplanada. Há uma sorpresa casi cotidiana com o lugar que se mantém viva há 47 anos. Quiçá a surpresa advenha da restauradora sensação de testemunhar uma utopia...

\section{Agradecimentos}

O autor agradece ao Conselho Nacional de Desenvolvimento Científico e Tecnológico (CNPq) pela Bolsa de Produtividade em Pesquisa, que permitiu esta investigação, e aos parceiros do grupo de pesquisa Dimensões Morfológicas do Processo de Urbanização (DIMPU), fonte perene de enriquecimento intelectual.

\section{Referências}

Bertaud, A. (2001). The costs of utopia. Recuperado em 1 de julho de 2007, de http://alain-bertaud.com/

Bertaud, A., \& Malpezzi, S. (1999). The spatial distribution of population in 35 world cities: the role of markets, planning, and topography. Wisconsin: Centre of Urban Land Economics Research. Working draft.

Botton, A. (2003). A arte de viajar. Rio de Janeiro: Rocco.

Brasil. (2019, 28 agosto). Estimativas da população de Brasília, tendo por referência 1o de julho de 2019. Brasília: Diário Oficial [da] República Federativa do Brasil. IBGE.

Coelho, J. M. (2017). Na riqueza e na pobreza: o papel da configuração para o estudo de centralidades e desigualdades socioespaciais em Brasília (Tese de doutorado). Faculdade de Arquitetura e Urbanismo, Universidade de Brasília, Brasília.

Costa, L. (1985). Brasília 57-85 (do plano-piloto ao Plano Piloto). Brasília: Terracap, Convênio SVO/DAU Terracap/DITEC. 
Costa, L. (1995). Lucio Costa: registro de uma vivência. São Paulo: Empresa das Artes.

Ferreira, M. M., \& Gorovitz, M. (2009). A invenção da Superquadra: o conceito de Unidade de Vizinhança em Brasília. Brasília: IPHAN.

Ficher, S., \& Palazzo, P. P. (2009). Paradigmas urbanísticos de Brasília. Revista da Biblioteca Mário de Andrade, (65), 93-121.

Garcia, C. C. (2009). Os desígnios da arquitetura: sobre a qualificação estética do desenho (Tese de doutorado). Faculdade de Arquitetura e Urbanismo, Universidade de Brasília, Brasília.

Giddens, A. (1984). The constitution of society. Outline of a theory of structuration. Cambridge: Polity Press.

Harari, Y. N. (2018). 21 lições para o século 21. São Paulo: Companhia das Letras.

Hillier, B. (1996). Space is the machine. Cambridge: Cambridge University Press.

Hillier, B., \& Hanson, J. (1984). The social logic of space. Cambridge: Cambridge University Press. http://dx.doi.org/10.1017/CB09780511597237.

Holanda, F. (2015). 10 mandamentos da arquitetura (2. ed.). Brasília: FRBH.

Holanda, F. (2018). O espaço de exceção (2. ed.). Brasília: FRBH.

Holanda, F. (2019). Construtores de mim. Brasília: FRBH.

Holanda, F., \& Barcellos, V. (2011). Permanência e inovação: SQN-109, Brasília. In F. Holanda (Ed.), Arquitetura e urbanidade (2. ed., pp. 120-139). Brasília: FRBH.

Holanda, F., Ribeiro, R., \& Medeiros, V. (2008). Brasília, Brazil: economic and social costs of dispersion. In Proceedings of the 44th ISOCARP Congress. Dalian: Dalian Publishing House.

Holston, J. (1993). A cidade modernista: uma crítica de Brasília e sua utopia. São Paulo: Companhia das Letras.

Instituto Brasileiro de Geografia e Estatística - IBGE. (2002). Base de informações por setor censitário: censo 2000: resultados do universo: Distrito Federal. Rio de Janeiro: IBGE.

Instituto Brasileiro de Geografia e Estatística - IBGE. (2011). Base de informações do Censo Demográfico 2010: resultados da Sinopse por setor censitário. Rio de Janeiro: IBGE.

Kohlsdorf, M. E. (1996). A apreensão da forma da cidade. Brasília: Editora Universidade de Brasília.

Kohlsdorf, G., \& Kohlsdorf, M. E. (2017). Ensaio sobre o desempenho morfológico dos lugares. Brasília: FRBH.

Mancini, G. A. (2008). Avaliação dos custos da urbanização dispersa no Distrito Federal (Dissertação de mestrado). Faculdade de Arquitetura e Urbanismo, Universidade de Brasília, Brasília.

Medeiros, V. A. S. (2006). Urbis Brasiliae, ou sobre cidades do Brasil: inserindo assentamentos urbanos do país em investigações configuracionais comparativas (Tese de doutorado). Faculdade de Arquitetura e Urbanismo, Universidade de Brasília, Brasília.

Medeiros, V. A. S. (2013). Urbis Brasiliae: o labirinto das cidades brasileiras. Brasília: Editora Universidade de Brasília.

Melo, J. C., No. (1968). Poesias completas (1940-1965). Rio de Janeiro: Sabiá.

Miragaya, J. (2013). Perfil da distribuição dos postos de trabalho no distrito federal: concentração no plano piloto e déficits nas cidades-dormitório. Brasília: CODEPLAN.

Ocaranza Pacheco, M. E. (2015). Os limites da gentrificação na Vila Planalto (Dissertação de mestrado). Faculdade de Arquitetura e Urbanismo, Universidade de Brasília, Brasília.

Peponis, J. (1989). Space, culture and urban design in late modernism and after. Ekistics, 56(334-335), 93-108.

Pérez de Arce, R. (2015). Urban transformations and the architecture of additions. London: Routledge. 
Ribeiro, R. J. C. (2008). Índice composto de qualidade de vida urbana. Aspectos de configuração espacial, socioeconômicos e ambientais urbanos (Tese de doutorado). Faculdade de Arquitetura e Urbanismo, Universidade de Brasília, Brasília.

Rodgers, R.; Gumuchdjian, P. (2001). Cidades para um pequeno planeta. Lisboa: GG.

Rykwert, J. (2000). The seduction of place: the city in the twenty-first century. London: Weidenfeld \& Nicolson.

Tenorio, G. (2012). Ao desocupado em cima da ponte: Brasília, arquitetura e vida pública (Tese de doutorado). Faculdade de Arquitetura e Urbanismo, Universidade de Brasília, Brasília.

Tonkiss, F. (2013). Cities by design: the social life of urban form. Cambridge: Polity Press.

Tönnies, F. (1887). Gemeinschaft und Gesellschaft. Leipzig: Fues's Verlag.

Zechin, P. D. A. V. (2014). Sobre a dimensão espacial da desigualdade social urbana. Um estudo sobre cinco cidades brasileiras (Tese de doutorado). Faculdade de Arquitetura e Urbanismo, Universidade de Brasília, Brasília.

Zein, R. V. (2001). O lugar da crítica: ensaios oportunos de arquitetura. Porto Alegre: Faculdades Integradas, Instituto Ritter dos Reis.

Editores convidados: Vitor Oliveira (Universidade do Porto, Portugal) e Bruno Zaitter (PUCPR, Brasil)

Recebido: Out. 25, 2019

Aprovado: Dez. 08, 2019 


\section{Errata}

No artigo "Inclusão e exclusão em Brasília", com o número de DOI https://doi.org/10.1590/21753369.012.e20190306, publicado na urbe. Revista Brasileira de Gestão Urbana, vol. 12, e20190306,

onde se lia:

Seção Temática: 0 Estudo da Forma Urbana no Brasil

leia-se:

Seção Temática: O Estudo da Forma Urbana no Brasil (Editores convidados: Vitor Oliveira e Bruno Zaitter) 